\section{WANITA KARIR MENURUT HUKUM ISLAM}

\section{Nurliana}

Sekolah Tinggi Agama Islam (STAI) Diniyah Pekanbaru

\section{Abstract}

Tulisan ini diberi judul Wanita Karir Menurut Hukum Islam Adapun tulisan ini bisa terwujud karena terinspirasi dari kondisi kehidupan saat ini, dimana para wanita lebih banyak yang memiliki karir di luar rumah, dengan alasan yang beragam, ada disebabkan karena tuntutan profesi yang dilatar belakangi oleh pendidikan yang yang bersangkutan, namun ada pula karena tuntutan kehidupan untuk mencari rezeki sebagai penopang kelancaran kehidupan dalam rumah tangga. Wanita karir yang dimaksudkan disini ialah para wanita yang memiliki karir di luar rumah, secara umum wanita dituntut untuk menjaga dan melaksanakan aktivitas sebagai Ibu rumah tangga, menjaga anak-anaknya dan menjaga harta suami serta melayani kebutuhan suami dan anak-anak seperti makan, minum dan mencuci pakaian. Di dalam Islam para wanita tidak diperintahkan untuk mencari nafkah karena yang bertanggung jawab terhadap nafkah adalah suami. Wanita muslimah boleh bekerja membantu suaminya, asal tidak memamerkan aurat atau menimbulkan kesombongan. la boleh keluar rumah, asalkan memang untuk suatu urusan yang dibenarkan syariat, tidak mengorbankan kehormatan dan kesucian dirinya. Wanita muslimah boleh dan harus menghayati hakekat suatu pekerjaan dan peran utamanya adalah ratu keluarga, petaka rumah tangga yang akan melahirkan manusia-manusia teladan, sebab dialah tiang negara, maju mundurnya negara tergantung pada wanitanya. Selanjutnya Islam melihat tentang hukum wanita karir diantaranya mubab (boleh-boleh saja) selama ia masih menjaga kodratnya sebagai wanita, sebagai ibu dan sebagai istri dan apa yang diperolehnya merupakan suatu ibadah sedekah terhadap rumah tangganya. Namun hukum tersebut bisa berubah menjadi haram, bila para wanita melalaikan tugasnya dalam rumah tangga dan bekerja tanpa izin suaminya.

Keywords: Wanita Karir, Peran Perempuan, Hukum Islam.

\section{Pendahuluan}

Wanita di sepanjang sejarah manusia, selalu memegang peranan unik dan strategis dalam kehidupan masyarakat, peranan mereka tak pernah dianggap kecil, bahkan selalu disejajarkan dengan pria dalam skala aktivitas masing-masing. Islam memberikan penghargaan akan peranan wanita dalam masyarakat, seperti halnya "Wanita adalah tiang negara", "Surga di bawah telapak kaki ibu", "Wanita membangun bangsa, pria membangun negara" dan lain sebagainya, bahkan pada dekade ini tahun 90-an dikatakan sebagai era kepemimpinan wanita. Keterlibatan dan peranan wanita dalam membangun masyarakat dan negara adalah penting berdasarkan kepada tugas dan tanggung jawab pada berbagai pembangunan negara yang dapat disejajarkan dengan kaum pria.

Secara umum Islam tidak menghalang kaum wanita untuk melakukan pekerjaan yang baik di luar rumah sekiranya ia merupakan keperluan diri dan keluarga atau untuk masyarakat dan negara. Atas dasar keperluan inilah wanita-wanita pada zaman nabi Muhammad saw. bekerja sama membantu keluarga mereka seperti mengembala, bertani, berdagang dan sebagainya. Sebagai contoh Asma' binti Abu Bakar yang bekerja sebagai petani untuk membantu suaminya dalam mengangkat hasil pertanian dari ladang ke pasar yang jauhnya kira-kira $1,4 \mathrm{~km}$.

Meskipun Islam datang dan berkembang di Indonesia lebih dari lima abada, pemahaman dan pengahayatan keagamaan kita masih cenderung singkretik, tarik menarik antara nilai-nilai luhur Islam dengan budaya lokal. ${ }^{1}$ Islam menganggap segala pekerjaan yang dilakukan oleh wanita atau laki-laki adalah ibadah. Ini karena ajaran

1 Atang Abddudin Nata, Jaih Mubarok, Metodologi Studi Islam, (Bandung: Remaja Rosda Karya: 2003), Cet. ke 6, hlm. 189 
Islam tidak memisahkan amalan manusia yang dilakukan dengan niat ikhlas dan tidak terlepas dari landasan dan peraturan Islam maka hal tersebut dapat dianggap sebagai amal shaleh.

Wanita dalam pandangan Islam adalah saudara laki-laki di sini mereka mendapat perhatian khusus, karena kelebihan mereka dari segi hak, kewajiban, tugas, baik mentarbiyah, mentakwil maupun membina, dimana hal itu bermuara dari satu manhaj ilmiah yang paripurna dan syamil, cocok dengan fitrah manusia, sejalan dengan elemen-elemen kehidupan. Manhaj yang pantang surut dalam arus perjalanan umat sesuai tujuan. Ia membimbing, mengarahkan kehidupan ini dan kemajuan peradaban agar mengarah kepada kemanusiaan dan memenuhi kebutuhannya. Jadi manhaj ini adalah pemandu dan pemberi petunjuk, dari manhaj inilah akan lahir wanita-wanita Mujabidah, ibu murobbiyah, kaya ilmu dan menghormati kemanusiaannya, tampil merobah wajah umat. Ia merupakan madrasah yang suatu saat akan menelurkan sosok-sosok lelaki gagah berani dan melahirkan pribadi-pribadi tangguh yang menguasai dunia. ${ }^{2}$

\section{Peran Wanita Muslimah yang Berkarir Pada Masa Sekarang.}

Islam menganjurkan umatnya untuk menikmati dunia dan apa yang ada didalamnya, dengan syarat tetap berada dalam batas-batas yang telah ditentukan oleh Allah. Islam bahkan mengharuskan manusia untuk memanfaatkan semua yang baik yang disediakan oleh Allah karena semua itu penopang kesejahteraan. ${ }^{3}$

Di era globalisasi tentu diperlukan perumusan ulang peran wanita yang relevan dengan tantangan zamannya. Mengingat perubahan zaman sedemikian cepatnya, dan perubahan tersebut menawarkan nilai-nilai baru yang mungkin tidak serasi sebagai penapisan sehingga tidak terjadi kekosongan nilai (anomi). Peran wanita sebagai pelaku utama sosialisasi primer tidak dapat disangkal.

2 Nurlaila Iksa, Karir Wanita Di Mata Islam, (Pustaka: Pustaka Amanah, 1998), Cet. 1, hlm. 9

3 Ali Abdul HAlim Mahmud, Akblak Mulia, (Jakarta: Gema Insani; 2004), Cet. 1, hlm. 165
Keluarga yang mendapat sosialisasi primer yang baik dan biasa memiliki perilaku dan sikap dasar yang baik. Sementara keluarga yang hanya mementingkan karir akan melahirkan generasi yang disosialisasi pembantu (biasanya pendidikan terbatas) serta disuapi susu sapi. Simak sebagai Einsten maupun Thomas alva Edison yang semula "tidak berbakat" namun berkat ketekunan sang ibu dalam mendampinginya, sampai sekarang tak seorangpun di dunia ini yang tidak menikmati karyanya.

Dalam konteks itu wanita dituntut memiliki peran yang multi dimensi. Berpendidikan tinggi, berwawasan luas, pintar, menjunjung tinggi nilai-nilai etika masyarakat serta mampu mendorong anak-anak berbudi luhur, jenius dan berdaya juang tinggi. Semua itu merupakan landasan bagi genarasi penerus yang akan menentukan nasib bangsa ini. Karenanya wanita harus memiliki keperibadian kuat dan teguh, berakhlak mulia serta peduli dalam segala hal. ${ }^{4}$

Berbicara tentang karir, yang terbayang di depan mata mereka adalah berbusana rapi, menenteng tas penuh lembaran uang puluhan ribu, dengan mobil Mercedes, BMW, Corona dan yang sejenisnya, mereka berangkat ke tempat kerja. Mereka umumnya berasal dari keluarga yang cukup berada bahkan berlebih, berpendidikan tinggi dan tinggal di kota-kota. Kondisi ini sangat menunjang karir atau melamar pekerjaan bergengsi, berkantor di gedung bertingkat dengan fasilitas serba lux.

Karir adalah karakter pekerjaan yang sering dipengaruhi adanya potensi individu yang bersangkutan dengan tanggung jawab dan tugastugas tertentu. Manusia di dunia ini selalu berlomba meningkatkan kekuatan dan jumlah hartanya, hingga dia menjadi orang terkuat diantara sesamanya dalam bidang kekuasan, paling manis tutur katanya paling kuat dalihnya dan paling banyak pendukungnya serta merasa tidak membutuhkan orang lain. Namun di saat zaman sudah berubah dan saat dia mengalami musibah (misalnya kekuasaan dan prestise yang selama ini ia bangga-banggakan hilang lenyap bersamaan dengan

${ }^{4}$ Muhammad Ali Al-Hasymi, Jati diri wanita muslimah, (Jakarta: Gema Insani, 2004), Cet. 1, hlm. 35 
pergantian zaman dan generasi), ia bagaikan anak kecil yang mencari bapaknya, merengek-rengek mancari bantuan dan belas kasihan orang lain. ${ }^{5}$

Karir merupakan kesinambungan proforsi ilmu dan kemampuan yang akan menghasilkan popularitas atau sesuatu yang bersifat materi. Karir juga merupakan upaya kerja yang sungguh-sungguh untuk mencapai tujuan tertentu dalam perioritas hidup bermasyarakat. Karir bisa berarti perwujudan prestasi yang ditempuh dengan kerja optimal pada bidang tertentu, seperti mengajar, menjahit dan lain sebagainya. Karir, adalah suatu aktivitas yang dijalani terus-menerus sejauh fisik memungkinkan. Karir yang benar adalah yang melibatkan pikiran, energi, kesungguhan dan kontinuitas.

Berdasarkan budaya hidup masyarakat Indonesia, keterlibatan kaum wanita dalam tugas-tugas di luar rumah adalah hal biasa namun menjadi kebiasaan bagi wanita bekerja membantu keluarga, ada sebagai petani, peternak dan pedagang. Keterlibatan mereka dalam kerja seperti ini tidak menimbulkan banyak masalah karena pekerjaan tersebut tidak terikat dengan berbagai peraturan. Namun permasalahan yang dihadapi pada zaman sekaranag ini adalah bagi wanita yang sudah berkeluarga dan memiliki anak harus terus bekerja untuk memenuhi kebutuhan keluarganya sehingga mereka tidak memiliki waktu yang cukup untuk keluarga mereka.

Salah satu tema utama sekaligus prinsip pokok dalam ajaran Islam adalah persamaan manusia, baik laki-laki maupun perempuan maupun antar bangsa, suku dan keturunan. Perbedaan yang digaris bawahi dan yang kemudian meninggikan atau merendahkan seseorang hanyalah nilai pengabdian dan ketaqwaan kepada Allah swt. ${ }^{6}$

Kalau kita kembali menelaah keterlibatan perempuan dalam pekerjan pada masa awal Islam, maka tidaklah berlebihan jika

5 Abdul Aziz bin Abdullah, 50 Nasehat untuk. Wanita Muslimah, (Jakarta: Gema Insani, 1994), Cet. Ke 9, hlm. 12-13

${ }^{6}$ Lihat Al-Qura'an dan Terjemah, Wahai seluruh manusia, sesungguhnya kami telah menciptakan kamu (terdiri) dari lelaki dan permpuan dan kami jadikan kamu berbangsa-bangsa dan bersuku-suku agar kamu saling mengenal, sesungguhnya yang paling mulia diantara kamu adlah yang paling bertaqwa. (Q.S. 49: 13) dikatakan bahwa Islam membenarkan mereka aktif dalam berbagai akivitas. Wanita boleh bekerja dalam berbagai bidang di rumah atau di luar rumahnya, baik secara mandiri atau bersama orang lain. Dengan lembaga pemerintah maupun swasta, selama pekerjaan tersebut dilakukan dalam suasana terhormat, sopan serta dapat menghindari dampak-dampak negative dari pekerjaan tersebut terhadap diri dan lingkungannya. Pekerjaan dan aktivitas yang dilakukan oleh perempuan pada masa nabi saw. cukup beraneka ragam, sampaisampai mereka terlibat secara langsung dalam peperangan, bahu membahu dengan kaum lelaki. ${ }^{7}$

Abdul Halim Abu Syuqqah dalam kitab Tahrir al-Mar'ah fi 'Ashr al-Risalah, mengemukakan bahwa Islam telah mengatur peran wanita dalam kehidupan sosial dengan etika yang sempurna, etika tersebut memiliki karakter sebagai berikut; pertama, etika tersebut tidak menghambat proses keseriusan hidup serta tetap mempertahankan akhlak dan harga diri manusia. Kedua, etika tersebut menumbuh kembangkan kesejahteraan dan kemakmuran menjauhkan manusia dari kemungkaran sekaligus menempanya sehingga tidak terseret arus

7 Nama-nama seperti Ummu salamah (istri nabi) Syafiyah, Laila alGhafariyah dan lain-lain, tercatat sebagai tokoh yang terlibat dalam peperangan. Ahli Hadis Imam Bukhari, membukukan babbab dalam kitab sahihnya yang menginformasikan kegiatankegiatan wanita, Seperti bab keterlibatan perempuan dalam Jihad, bab peperagan kaum perempuan dalam lautan, bab keterlibatan kaum perempuan merawat korban, dan lain-lain. Disamping itu para perempuan pada masaNabi saw. Aktif pula dalam berbagai pekerjaan ada yang bekerja sebagai perias pngantin, seperti ummu Salim binti malhan yang merias, ada juga yang menjadiperawat, bidan dan lain sebaginya. Namun dalam bidang perdagangan Nama istri Nabi yang pertama Khadijah binti Khuwailid tercatat sebagai seorang yang sukses. Perempuan yang pernah datang kepada nabi meminta petunjuk tentang jual-bali, pesan nabi diantaranya tentang jual beli menyangkut tentang penetapan harga jual-beli . Istri Nabi Zainab binti Jahsy juga aktif bekerja sampai pada menyamak kulit binatang, dan hasil usahanya itu beliau sedekahkan. Raitih, Istri sahabat nabi Ibnu Mas'ud sangat kti bkerja karena suami dan anaknya ketika itu tidak mampu mencukupi kebutuhan hidup keluarga. Al-Syifa seorang permpuan yang pandai menulis ditugaskan oleh Khalifah Umar ra. Sebagai petugas yang menagani pasar Kota Madinath. 
kejahatan. Ketiga, etika tersebut menjamin kesehatan mental laki-laki dan wanita secara merata karena tidak membuka peluang sikap berlebihan, melanggar norma, asusila atau memancing syahwat. Selain itu etika itupun tidak menimbulkan sikap pura-pura malu, tidak menimbulkan perasaan sensitif yang berlebihan terhadp lawan jenis, serta tidak menimbulkan seorang wanita menutup diri dari seorang laki-laki. Sebaik-baik urusan adalah pertengahan. ${ }^{8}$

\section{Dampak Individual Wanita Karir.}

Diera Informasi saat ini tampaknya orang sudah tidak lagi menghiraukan nilai-nilai agama, juga tidak mengenal nilai-nilai budaya bangsa, sehingga menimbulkan gegar budaya. Mengapa terjadi demikian ? Karena "wanita" sebagai pusat peradaban tidak menjalankan fungsinya sebagaimana layaknya. Orang boleh maju tetapi harus konsisten (istiqomah) terhadap nilai-nilai luhur. ${ }^{9}$

Para pakar ilmu-ilmu sosial sering membahas norma dalam pranata sosial, akan tetapi kebanyakan mereka cenderung berpikir sekuler, ingin mencoba melepas diri dari tuntutan fitrah sang pencipta. Manusia yang ada, hendak diajak lari dari dirinya sendiri, menyusuri lorong gelap tanpa petunjuk. Beginilah bila manusia dilepas, manusia akan saling menindas, yang berkuasa berbuat semaunya. Mereka ditunggangi nafsu, beraksi mengatasnamakan "tuntutan zaman". Norma menjadi hak mereka yang kuat, untuk diperalat sebagai sarana untuk duduk di singgasana kezaliman. Tak luput kalangan wanita yang secara fisik biasanya lebih lemah, bahkan pria lebih kuat jelas sudah, inilah sesungguhnya yang dibela Islam. Sungguh jika kita menengok ajaran Islam yang datang dari Dzat yang mengetahui seluk beluk manusia akan terlihat keagungan. Dia yang mencipta, Dia pula yang mengatur semua ciptaanNya. Juga manusia antara pria wanita. Allahlah yang membebaskan dari tindak kezaliman manusia itu sendiri.

8 Abdul Halim Abu Syuqqah, Kitab Tabrirul Mar'ah Fii Ashrir Risalah (Beirut: Dar al-Banah,1969), hlm. 33

${ }_{9}$ Ibid, hlm. 20
Bekerja di rumah dan di luar rumah adalah karir, yang dibutuhkan adalah menghayati pekerjaan dan melakukannya penuh tanggung jawab. Dalam sebuah hadist dinyatakan:

"Muslim yang baik adalah yang tekun terhadap profesinya"

"Dari Ibnu Mas'ud r.a, nabi shallallahu alaihi wasallam bersabda: dari kebaikan sifat seseorang mukmin adalah yang tekun terhadap semua pekerjaannya". (H.R. Thahrani).

Wanita yang bekerja di luar rumah banyak yang tidak dapat menyesuaikan diri dengan baik, sehingga cukup banyak yang enggan memberikan kedudukan penting atau yang memerlukan tanggung jawab dari wanita, karena sering kali mereka punya banyak alasan yang membuat tugas mereka tak berjalan mulus. Tatkala anak mereka sakit terpaksa tidak masuk kantor, tatkala cekcok dengan suami mereka terlambat datang. Dampak karir akan menimbulkan beban ganda yang melelahkan dan menyita perhatian, maka bila wanita bekerja di luar rumah, ia harus mempunyai seorang yang dapat dipercaya untuk mengurus anaknya. Kecuali jika sakit keras tentu ayah dan ibunya harus turun tangan meskipun bekerja di rumah atau di luar rumah.

Secara individu ia harus menyusun jadwal waktu dengan penuh disiplin. Wanita yang membangun adalah wanita yang tahu mengatur waktunya, mengurus rumah tangga seefisien mungkin. Bila karir tak dapat dielakkan tentu manajemen rumah tangga terabaikan, tugas berantakan, pendidikan anak jadi terlantar, kasih sayang tersia-siakan dan akhirnya pra-muwisma yang mengendalikan rumah tangga, Nyonya rumah amat tergantung pada pramu-wisma, walau ia kurang sopan pada tuan rumah dianggap membiasa. Secara tidak langsung turunlah harkat kewanitaannya di tengah-tengah keluarga. ${ }^{10}$

Di dalam keluarga hendaknya berlangsung; [1] Saling meneguhkan aqidah, [2] Membiasakan beribadah baik yang wajib maupun sunat, [3] Mengaktualisasikan nilai-nilai agama dalam perilaku sehari-hari, dan [4] Mewujudkan rumah tangga sebagai tempat

${ }^{10}$ La Rose, Dunia Wanita, Rumah Tangga, Memiliki Seribu Tangan, (Jakarta: Pustaka Kartini, 1989), hlm. 109 
kegiatan ilmiah (mengkaji ilmu-ilmu bermanfat) dan membangun kekuatan fisik dengan membiasakan dalam perilaku makan yang baik.

Endang Syaifuddin Anshari, seorang Mubaligh dan seniman menyampaikan ungkapan K.H. Nursyad Nurdin "Mendidik seorang anak laki-laki adalah mendidik seorang saja, sedang mendidik seorang wanita adalah mendidik sebuah keluarga", dengan demikian tampak bahwa peran dan kedudukan wanita lebih kompleks dari pria. ${ }^{11}$

\section{Dampak Sosial Wanita Karir.}

Menjadi wanita memang menyenangkan, apalagi wanita muslimah, muslimah berarti wanita yang telah diseleksi oleh Allah untuk menerima hidayahnyaNya dan menjalankan kehidupan sesuai Sunnah Rasul. Pada waktu Rasulullah saw. masih hidup, kaum wanita merasakan angin segar dalam kehidupannya, setelah sebelumnya pada hidup teraniaya, tidak mendapatkan hak yang semestinya. Kehidupan wanita pada saat itu beruntung dibandingkan dengan wanita sekarang pada umumya. Karena muslimah relatif hidup dalam komunitas masyarakat yang memahami nilai Islam dengan baik. Hidup mereka betul-betul tersanjung karena mereka hidup sesuai fitrahnya.

Berbeda dengan sekarang ketika banyak wanita menuntut emansipasi, persamaan derajat, boleh dikatakan kehidupan wanita sekarang berada di tengah komunitas yang tidak memahami nilai-nilai Islam, ini menyebabkan ketidaknyamanan dalam hidup mereka. ${ }^{12}$ Abad ini, tak lagi dikenal era nuklir, melainkan era informasi, era ini membawa tantangan yang tak kurang bahavanya bagi manusia khususnya muslim. Dengan kian canggihnya ilmu pengetahuan dan teknologi arus informasi semakin deras membanjiri dunia Islam karena jarak dan waktu tidak lagi menjadi kendala, sementara itu kian banyak muslim dan muslimah yang tidak memiliki furqon. Sebagai akibatnya terjadilah penyerapan budaya dan informasi tanpa selektif.

${ }^{11}$ Najwan Farjy, Pdoman Pembinaan Anak Dalam Islam, (Jakarta: Unisef, 1986),

12 Syekh Muhammad Bin Ibrahim dkk, Panduan Ibadah Wanita Muslimah, (Yogyakarta: Darussalam Offset, 2004), hlm. 24
Emansipasi dan karir akan mengeluarkan wanita dari tempatnya yang suci dan tinggi. Dalam kedudukannya sebagai ratu rumah tangga, pilar keluarga menjadi pekerja yang hanya mendapat upah separuh laki-laki. Perginya wanita dari rumah dan kodratnya sebagai manager rumah tangga akan selalu diikuti oleh hancurnya sebuah generasi sebagai akibat tidak berfungsinya ibu sebagai madrasat al-aulad. Muslimah diberikan Allah amanah melahirkan dan menempa generasi yang diridhai yang akan menentukan wajah zaman mendatang. Bila wanita bekerja pada beberapa sektor eksklusif sebagai manager, memegang jabatan di kantor-kantor, sebagai pelayan di restoran, aktris, penari, model dan sejenisnya yang sama-sama bisa dijalani oleh kaum lelaki niscaya para lelaki akan tergeser keaktifannya dalam dunia karir, besar kemungkinan prosentase penganggur akan semakin meningkat. Akhirnya stabilitas sosial terganggu, belum lagi bila penyelewengan terjadi, wanita berlaku bengkok, menggunakan tangan kirinya, masyarakat akan goyang berantakan, dekadensi moral merajalela, fitrah kewanitaannya tersia-siakan. ${ }^{13}$

\section{Dampak Positif Wanita Karir.}

Tugas wanita sesungguhnya adalah berusaha membina model kehidupan pribadi, keluarga dan masyarakat. Ini awal dari aktivitas dakwah. Orang lain yang belum mengerti akan melihat hal itu sebagai bentuk ajaran yang patut dicontoh. Akhlak mulia merupakan hal utama dalam kehidupan sehari-hari, penilaian hati (bashiroh) yang tepat adalah pemilah akurat untuk melihat kebajikan yang akan diikuti tanpa dilepaskan dan melihat keburukan sebagai sinyal kewaspadaan ia tidak tertarik pada hal-hal yang akan menjauhkan dirinya dari Allah, meski dirayu dengan apapun. Sama halnya dengan karir atau pekerjaan yang harus diselesaikan di luar rumah itu hanya karena motivasi yang murni, mendakwahi orang lain dan mentarbiyahnya. Karena cintanya terhadap kebenaran melebihi segala-galanya. Ia lebih cinta hidup

${ }^{13}$ Laila, Wanita Karir... hlm. 23 
menderita dan jihad daripada hidup bergelimang materi dan kemewahan. ${ }^{14}$

Dampak positif bagi karir wanita muslimah akan membawa kemaslahatan umat, pekerjaannya bukan untuk publikasi namun semata karena Allah, lantaran kepribadiannya, ia bersegera melaksanakan yang lebih baik dan tampil bersama ahlul khair dengan berdoa "ya Allah jika kau tolong aku, maka selamatkanlah dien-Mu dan bila kau binakan aku, maka dien-Mu men-jadi terbina".

Wanita juga penyambung estafet, ini peran yang lebih besar lagi sebagai pendidik generasi pelanjut, ia benar-benar akan dapat mewarnai wajah masyarakat, jika wanita di suatu wilayah kerja berlaku lurus dan benar menggunakan tangan kanannya, maka di situ akan terdapat masyarakat manusia mulia. Memang, wanita selalu menjadi barometer akan baik buruknya masyarakat, kondisi mental dan akhlak manusia. Wanita adalah tiang negara, besar kemungkinan mampu berkarya dan bekerja lebih teliti, ia dapat menyangga, menegakkan bangunan dan stabilitas kerja yang islami. Biarpun laki-laki adalah motor pelaksana aktivitas, tanpa dukungan dan "back up" dari wanita mereka akan gagal. Lelaki adalah makhluq perkasa fisiknya tapi lemah perasaannya sehingga perlu dorongan yang lembut yang dapat membangkitkan kerja dan dakwah islamiyah. Pekerjaan yang terhormat bila dilakukan muslimah besar kemungkinan akan membawa masyarakat yang luhur dan hormat. Tiada lagi pasien putri yang harus dirawat kaum lelaki yang sering berdampak tidak sehat disamping mengembangkan potensi yang mereka miliki sebagai syukur yang sesungguhnya. Bila misalnya tidak ada muslimah yang keluar untuk berdakwah kepada masyarakat (kaum ibu) siapa yang akan meneruskan misi Rasulullah sebagaimana dilakukan ummahatul mukminin terdahulu, tugas siapa untuk mengonter informasi kejahiliyahan yang menimpa umat.

Sesungguhnya manusia itu bagaikan binatang apabila ia tidak berpegang teguh pada hukum-hukum Allah, dan tidak mengadakan hubungan dengan Dia serta tidak mengharap bertemu denganNya,

${ }^{14}$ Ibid, hlm. 23 hawa nafsunya dituruti, sibuk terhadap dirinya sendiri dan tidak memberikan manfaat kepada orang lain. Berbeda dengan muslimah yang benar dan jujur. Dia berangkat dari ajaran-ajaran agama (Islam), senang melihat manusia yang berada dalam kebaikan dan selalu diulurkan tangannya untuk menolong orang lain. Iapun benci apabila manusia berada dalam kenistaan dan kebodohan. ${ }^{15}$

Itulah dampak positif yang juga dinantikan oleh generasi demi generasi sehingga dapat mengambil keteladanan yang normatif, islami dan arif. Sementara dari sisi materi hanyalah sebagai sarana bersedekah dan amal shaleh. Bila istri bekerja untuk membantu suami adalah pahalanya lebih besar dari nafkah fisabillah. Jadi karir yang dilakukan karena desakan ekonomi sementara ia memiliki potensi untuk membantu meringankan beban keluarga itu diperbolehkan sebab merupakan sedekah. Seorang wanita yang bekerja di satu bidang, di luar rumah dapat diharap menjadi bunga mekar, semerbak baunya di antara rekan yang berbeda orientasi dan latar belakang dengan identitas dan kepribadian yang luhur dapat menyebarkan harumnya kebenaran di tengah-tengah mereka. Sebagai sosok yang tangguh, mengemban amanat dengan positif tanpa mengandalkan orang lain. Semua dalam rangka dakwah ilallah. Tanamlah dalam kalbmu rasa kasih sayang dalam kelembutan, sayangi yang muda hormati yang tua darimu, hingga kepada binatang melatapun berlakulah demikian. ${ }^{16}$

15 Di antara keistimewaan seorang muslimah adalah hatinya selalu bergantung pada Allah Ta'ala, menerapkan syari'at-syari'at Nya serta menjalankan segala perintahnya. Kesejukan jiwa dan ketenangan hati bisa dilihat oleh mereka yang senantiasa tegar dalam meghadapi berbagai masalah, dan tidak terburu-buru dalam meraih apa yang ia inginkan. Lihat Abdul Aziz Bin Abdullah al-Muqbil, 50 nasehat Untuk Wanita Muslimah, (Jakarta: Gema Insani, 2004), Cet. Ke 9, hlm. 13

16 Ada seorang laki-laki yang sedang melakukan perjalanan. Ditangah jalan ia merasa haus sekali kemudian ia menemukan sumus itu, dan minum air tersebut, ketika keluar dari sumur itu, dan minum air sumur tersebut. Ketika keluar dari sumur itu ia melihat anjing menjulurkan lidahnya sambil makan tanah karena kehausan. LAki-laki itu berkata dalam hatinya pasti anjing itu kehausan seperti yang baru saja kualami. Maka ia turun lagi kedalam sumur untuk mengambilkan air untuk anjing tersebut dengan memakai sepatunya. Para sahabat bertanya ya 


\section{Dampak Negatif Wanita Karir.}

Kalau kita melihat kiprah wanita dalam sejarah kemanusiaan dan segala sepak terjangnya hari ini rasanya statement tersebut dapat dibenarkan, sejarah masa lalu umat manusia di sana-sini penuh penyelewengan kaum wanitanya. Dari sisi lain dapat kita saksikan bahwa penyelewengan para lelaki sering terkait dengan keberadaan wanita. Contohnya kisah pembunuhan pertama di dunia, dimana Qobil membunuh saudaranya Habil, itu karena persoalan wanita. Wanita memang bisa menjadi subyek sekaligus obyek kedurhakaan kepada Allah. Pelacuran misalnya, menurut beberapa pakar adalah bisnis manusia tertua. Sejarah juga mencatat nama-nama seperti istri nabi Luth, Null, Zulaikha yang menggoda nabi Yusuf a.s. Namun terdapat kesalahan pada tataran hukum dan perundang-undangan diskriminasi terhadap kaum permpuan di Indonesia pada level praktis memilkii pembenaran. Nursyahbandi menceritakan nasib perempuan di Indonesia yang masih akrab dengan diskriminasi. Ia menunjukkan dari sektor ketenaga kerjaan, kaum perempuan kerap diperlakukan tak adil, dari soal gaji, kesempatan hingga persepsi umum. ${ }^{17}$

Dewasa ini penyelewengan wanita terhadap syariat Allah semakin menjadi-jadi, runtutannya mungkin dapat kita mulai pada gagasan emansipasi wanita yang dicanangkan oleh musuh-musuh Islam, gagasan ini jelas sangat fatal, karena hal itu berarti mengalihkan wanita dari tugas utamanya untuk mendidik anak-anak dan mencabut wanita dari akarnya yaitu rumah, akibatnya generasi mendatang sudah dapat kita ramalkan, sebagaimana petunjuk yang terdapat dalam $\mathrm{Al}$ Qur'an: artinya, Maka datanglah sesudah mereka generasi yang menyia-nyiakan shalat dan mengikuti syahwat, maka kelak mereka akan menemui kesesatan. (Q.S. Maryam : 59)

Kemudian upaya emansipasi ini membutuhkan kreativitas dan kegesitan, maka yang menjadi sasaran berikutnya untuk diganyang

Rasulullah apakah kita mendapat pahala walaupun menolong anjing ? Rasul menjawab, ya tentu siapa saja Ibid, hlm. 50

17 Luthfi Asyaukani, Politik Ham Dan Isu-isu Teknologi Dalam Fikih Kontemporer, (Bandung: Pustaka Setia, 1998), Cet. 1, hlm. 133 adalah busana muslimah yang dianggap menghambat ruang gerak dan diganti dengan pakaian-pakaian merangsang dan memancing sejumlah kejahatan seksual. Hal itu terjadi, karena syahwat laki-laki yang terbesar, adalah pada wanita. Sebuah statement "mayoritas wanita penghuni neraka", tampaknya tidak bisa kita nilai secara kuantitatif, tapi harus dilihat sebagai peluang, artinya: apa yang disaksikan Rasulullah pada peristiwa Israk Mi'raj menunjukkan besarnya peranan wanita dalam menggiring arah perjalanan umat ini ke sorga atau neraka. Nabi bersabda:

"Golongan dari ahli neraka yang aku belum pernah melihatnya (tapi nanti akan menjadi kenyataan), yaitu satu kaum (yang zalim dan kejam), mereka membawa cambuk seperti ekor sapi, mereka memukul orang-orang dengannya. Dan wanita-wanita yang berpakaian menarik, memikat birahi orang. Mereka memperlihatkan kecantikannya, sanggulnya besar seperti pungguk punggung unta, mereka tidak akan masuk sorga dan tidak akan mencium baunya yang wanginya itu tercium dari tempat yang sangat jauh. ${ }^{18}$

\section{Dampak Wanita Karir Pada Peradaban}

Wanita dengan struktur tubuh yang lemah, tetapi Allah yang Maha Kuasa menciptakan bagian-bagian tertentu dari seorang wanita begitu kuat dan kokoh, agar mereka bisa mengandung, melahirkan, membesarkan seorang anak sebaik mungkin. Perhatikan struktur otot rahim wanita dengan lapisan otot yang saling menyilang laksana anyaman, merupakan struktur yang amat menakjubkan, karena struktur rahim normal sebesar telur ayam dapat membesar ratusan kali lipat beratnya semasa mengandung seorang bayi.

Dulunya manusia hidup berpindah-pindah, wanita tinggal di gua, memasak, merajut dan membesarkan anak-anak. Maka dalam peradaban kuno kita kenal awal mula dari peralatan memasak dan menjahit, semuanya dapat dipegang oleh tangan wanita yang kecil dan

18 Muslim, Shabih Muslim, Juz. VI., hlm. 168 
mungil, sampai sekarang ilmu bercocok tanam, meracik obat, merawat dan sebagainya masih dikuasi oleh sebagian besar kaum wanita. ${ }^{19}$

Di pihak lain, pria mempunyai sosok tubuh yang kekar sehingga merekalah yang berburu, mencari bahan makanan, berlayar dan sebagainya akhirnya mereka menguasai ilmu perbintangan, navigasi, mekanika fisika dan lainnya. Dengan semakin modernnya perkembangan peradaban manusia dari sudut pandang penguasaan ilmu dan teknologi, perbedaan "gender" ini hampir tidak dapat ditemukan lagi. Terkikis nilai-nilai kelembutan dan kewanitaannya akhirnya kasih sayangnya kian tipis habis.

Bahkan banyak kita jumpai wanita berkepribadian yang hampir sama dengan lelaki, prestatif, rasional, melepaskan diri dari kungkungan tradisi dan image lemahnya dengan mempertajam olah pikirnya, pada gilirannya kita temukan para wanita mengemudikan kendaraan-kendaraan berat, kemudinya dibuat sangat ringan. Mesinmesin produksi bisa dioperasikan pula oleh wanita, karena telah dilakukan otomatisasi, komputer misalnya dirancang agar dapat digunakan oleh tangan pria dan wanita, hal ini memang membantu kemajuan peranan wanita dalam kehidupan bermasyarakat.

Namun bagaimana dampak lain yang menampilkan koki laki-laki atau laki-laki berbelanja di pasar-pasar, menggantikan peran wanita. Hampir tak ada pekerjaan yang hanya dapat dikerjakan wanita saja atau hanya dapat dikerjakan oleh pria saja, secara berangsur kodrat dua makhluk ini jadi berubah. Sementara wanita jelas tak sama dengan pria. Wanita punya kelembutan, kasih, setia pada anak dan suami, sedang pria punya ketegasan dan sedikit realistis, itu adalah modal untuk memimpin rumah tangga. Dan benar laki-laki adalah pemimpin bagi wanita sebagaimana tersurat dalam al-Qur'an, Q.S. An-Nisa' : 34.

"Kaum laki-laki itu adalah pemimpin bagi kaum wanita, oleh karena Allah telah melebihkan sebahagian mereka (laki-laki) atas sebahagian yang lain (wanita), dan karena mereka (laki-laki) telah menafkahkan sebagian dari harta mereka. sebab itu Maka wanita yang saleh, ialah yang taat kepada Allah lagi memelihara diri.

${ }^{19}$ Laila Iksa, Wanita Karir... hlm. 34
Peradaban tersebut menurut Islam merupakan tindak yang tidak normatif, sebab Islam sebagai agama fitrah mengajarkan agar manusia mengikuti garis kesuciannya, agar dapat meraih derajat tinggi dan manusiawi. Peradaban baik dan buruk adalah ukuran penilaiannya, disebut baik bila mereka hidup dengan kendali jalur ilahi, sebaliknya dikatakan jelek bila keluar dari ketentuanNya.

\section{Karir Menurut Islam}

Islam sebagai agama integral, memberikan perioritas hikmat dan hormat, wanita menempati posisi khusus dengan kepiawaian dan bisa bergerak di bidang perluasan ilmu pengetahuan tanpa mengekang hakhaknya. Islam tak melarang, bahkan mewajibkan setiap warganya bekerja untuk kemajuan Islam. Dalam al-Qur'an wanita dipandang sebagai pribadi independen, Allah memelihara hak-hak penuh bijaksana, wanita diberi hak untuk berbudaya, berkarya cipta, agar dapat berapresiasi dan berkreasi di muka bumi secara benar sesuai dengan petunjuk-Nya, karena Allah telah mengangkat manusia sebagai khalifah di bumi. Dengan memahami semua itu wanita akan konsisten terhadap eksistensi keislamannya, terbentang pengetahuannya, mengenal sosok wanita dari zaman ke zaman dan tidak akan terbawa oleh arus kultural yang menyesatkan.

Islam tidak menganjurkan wanita bekerja mencari nafkah di luar rumah, tapi juga tidak melarang, bila keadaan memaksa, dalam artian tak ada lagi orang yang bisa diharap menanggung biaya hidup. Sejarah memperlihatkan profil Khodijah, wanita cantik, pintar, kaya dan hanif, berhasil dalam karya, perdagangan yang dilakukannya untuk mendanai kebutuhan dan kepentingan Islam dan muslimin sehingga meski bertugas ganda tapi tidak mengabaikan peranan utamanya. Demikian juga Asma' putri Abu Bakar yang mengerahkan segenap kemampuannya untuk membantu kelancaran dakwah sang suami, Zubair yang taqwanya sebagai aset ukhrowi yang tak dapat ditukar dengan benda apapun dari perhiasan dunia. Asma' sebagai istri, mengurus kudanya, pekerjaan yang menurut kriteria banyak wanita modern sebagai pekerjaan kasar, Asma' melakukan dengan ikhlas hati 
tanpa rendah diri, bantuan yang diberikan kepada suaminya, berarti bantuan kepada dakwah Islam.

Kategori karir dalam Islam pasti mengandung unsur dakwah dan merupakan esensi amal islami. Setiap muslimah harus meyakini sepenuhnya peranan yang besar terhadap diri, keluarga dan umat, pengaruhnya dalam pembinaan keluarga dan masyarakat. Oleh karenanya ia harus memperhatikan bekal spiritualnya agar bila menghadapi banyak tugas dan tanggungjawab, tidak merusak hubungannya dengan Allah. Selain ia bisa mengubah adat menjadi ibadah dan memanfaatkan setiap detik dari waktunya untuk mengingat sang Pencipta, mampu memonitor iklim rumah, mengatur waktu dengan baik, membuat skala kerja yang islami dan normatif. ${ }^{20}$

Dalam setiap masyarakat, wanita selalu mendapat peranan dan pekerjaan. Akan tetapi tugas utama adalah bekerja untuk generasi baru, membentuk karakter, perilaku dan etika islami. Bila ia hendak kerja lebih dari itu, seharusnya merupakan pekerjaan sambilan yang berarti tidak menelantarkan tugas utama. Misalnya harus disesuaikan dengan kemampuan, keahlian dan tidak menerobos hijab, karena akan merendahkan martabat wanita. Karena itu pekerjaan wanita harus berada pada interval khusus, berbeda dengan pekerjaan kaum pria dan ada batas yang mengendalikan keteraturan hubungan kedua jenis manusia itu. Islam mengajarkan pembatasan hubungan antara pria dan wanita guna menjaga martabat wanita agar tidak ternoda. Perlu diketahui bahwa Islam tidak melarang pria bertemu dengan wanita, tetapi Islam memberikan batasan dan aturan. Demikian juga Islam memberikan kemerdekaan dalam bekerja, berkarya yang harus ada tolak ukur yang berbeda antara pria dan wanita, termasuk dalam menghargai hasil pekerjaannya. Adalah sangat tidak adil bila mengukur wanita dengan standar pria. Karir harus sesuai dengan fitrah dan manhaj robbani.

\section{Wanita Karir Menurut Hukum Islam}

${ }^{20}$ Laila Iksa, Wanita Karir... hlm. 24
Din dalam bahasa Semith berarti undang-undang atau hukum, dalam bahasa Arab kata ini mengandung arti menguasi, menundukkan patuh, hutang, balasan, kebiasaan. Agama memang membawa aturanaturan yang merupakan hukum yang harus dipatuhi orang, dan menguasai diri seseorang dan membuat ia tunduk dan patuh kepada Tuhan dengan menjalankan ajaran-ajrn agama. Agama membawa kepada kebajikan-kebajikan yang kalau tidak dijalankan oleh seseorang menjadi hutang baginya. ${ }^{21}$

Dalam al-Qur'an manusia berulang-ulang diangkat dan direndahkan derajatnya. Mereka dinobatkan jauh mengungguli alam, surga, bumi dan bahkan malaikat, tetapi pada saat yang sama manusia bisa tak berarti dibandingkan dengan setan terkutuk dan binatang, manusia sebagai makhluk yang mampu menaklukkan alam namun merka juga bisa menjadi makhluk paling rendah. ${ }^{22}$

Beberapa dasawarsa belakangan ini kita menyaksikan munculnya feminisme atau gerakan pembebasan wanita, feminisme makin meluas dan teoritis menilik seluruh aspek kehidupan serta menepis semua konstruksi teoritis dan kerangka pendekatan dalam memahaminya. Mereka mengkaji peran dan fungsi hukum dalam kaitannya dengan perempuan sebagai hasil studi mereka, mereka mebuat opini sendiri tentang hakikat hukum. Inilah yang disebut teori feminis dalam hukum. ${ }^{23}$ Konsep yang terkait dengan gender adalah konsep peran. Peranan adalah apa yang diharapkan oleh masyarakat yang harus dimainkan oleh warga. Contohnya dalam lapangan pekerjaan setiap masyarakat biasanya memilih jenis pekerjaan yang cocok buat laki-laki dan cocok buat perempuan. Bagi sebagian besar masyarakat kita pekerjan supir truk buat pria, juru rawat bagi wanita, juru masak boleh kduanya, peran gender juga terkait dengan tingkah laku interpersonal, seperti jika pacaran lazimnya pria yang mentraktir, bukan sebaliknya.

${ }^{21}$ Harun Nasution, Islam Ditinjau Dari Berbagi Aspeknya, (Jakarta: UII Press, 1985), Cet. Ke 5, hlm. 1

${ }^{22}$ Zainuddin dan Muhamd Jamhari, Al-Islam 2 Muamlah dan Akblak, (Jakarta: Pustaka Setia, 1990), Cet. Pertama, hlm. 120

${ }^{23}$ Nur Ahmad Fadhil Lubis, Yurisprudensi Emansifatif, (Bandung: Cita Pustaka Media, 2003), Cet. Ke 1, hlm. 35 
Secara umum dapat disimpulkan bahwa setiap masyarakat memilki norma dan setiap warga ingin hidup normal dengan mengikuti norma tersebut. Ada empat jenis norma yang mengatur hidup dan kehidupan manusia; norma adat atau tradisi, norma agama, norma hukum, dan norma susila.. ${ }^{24}$ Teoritis feminis mengemukakan bahwa hukum disadari atau tidak biasanya absen dari wilayah domestik dan akibatnya wanita yang lebih banyak berkiprah di wilayah ini dibiarkan tanpa perlindungan menghadapi dominasi pria. Dalam banyak situasi wanita disingkirkan atau dikucilkan dengan alasan bahwa ia merupakan persoalan pribadi atau wilayah rumah tangga dimana hukum sebaiknya tidak turut campur.

Satu sisi wanita berada pada posisi lemah dan sisi lain dominasi pria malah semakin diperkuat. Contohnya dalam hukum perikatan tidak ada kesepakatan dapat dijalankan kecuali memenuhi persyaratan tertentu. Di banyak sistem hukum ini termasuk izin suami bagi wanita menikah, tetapi biasanya tidak diperlukan izin istri bagi pria yang berumah tangga. Pemisahan wilayah publik dan domain privatdomestik memang sering menyudutkan kaum wanita. ${ }^{25}$

Siapa di antara wanita muslimah yang menginginkan kedudukan terhormat, mulia disisi Allah serta tidak diganggu oleh laki-laki, maka tanamkanlah ketaqwaan, keimanan, mendekatlah diri kepada Allah dengan menjalankan apa yang diperintahkan dan pakailah pakaian yang menutupi aurat ketika berada di luar rumah, Insya Allah kehormatan akan terjaga serta dijauhkan dari gangguan laki-laki. ${ }^{26}$

Masalah yang dihadapi wanita, makin banyak dan sulit, rumit, kompleks, karena wanita harus berada di mana-mana, di pabrik, di kantor, di organisasi sosial bahkan di posisi penting pemerintahan, sementara letak dasar wanita paripurna harus tetap di dalam rumah, di samping suami, di jangkauan anak-anak tercinta, di lingkungan keluarga, di ajang pergaulan sesama manusia. Justru di situ letak

\section{${ }^{24} \mathrm{Ibid}, \mathrm{hlm} .37$}

25 Ibid, hlm. 43

26 Baidowi Syamsuri, Wanita Dan Jilbab, (Surabaya: Anugrah, 1993), Cet. Pertama, hlm. 182 masalah, lantaran wanita makin cenderung lalai pada fitrahnya. Secara umum dapat diketahui bahwa wanita salehah adalah wanita yang selalu menunaikan perintah Allah dan menjauhi laranganNya. Karena dengan taat kepada Allah dengan sendirinya akan taat kepada Rasul sehingga ia akan punya tanggungjawab moral dan peran besar terhadap kehidupan masyarakat dan mengetahui tanggung jawab hari ini dan hari sesudah kematian. Sehingga ia menyempatkan diri untuk melengkapi dirinya dengan ilmu dan iman, khususnya ilmu yang akan menjunjung harkat dan martbatnya dalam pandangan manusia dan Tuhan. ${ }^{27}$

Dari zaman dulu tugas alamiah wanita memang menjaga rumah tempat tinggal keluarganya, mengurus anggotanya, tidak meninggalkan rumah. Kemudian semakin bertambah umur bumi ini keadaan alamiah terusik dengan hasil pola pikiran yang disebut budaya. Dalam perjalanan sejarah, disintegrasi biasanya terjadi karena wanita mulai meninggalkan rumah. Pada abad ke $5 \mathrm{M}$, Yunani bangsa yang paling tinggi budayanya, waktu itu wanitanya tinggal di rumah, akan tetapi zaman sesudah Alexander, kota tersebut mulai mengalami keruntuhan, disitulah mulai terjadi feminist movement seperti emansipasi di masa kini. Di sinilah mulai timbul dampak dari wanita karir, dampak itu bukan saja menimpa wanita sendiri tetapi juga keluarganya. Namun jika ditanya kepada wanita masa kini, agaknya hampir tak mungkin mendapatkan jawaban dari mereka yang menyatakan ingin tidak keluar rumah. Karena itu, untuk meluruskan pandangan tersebut, harus dengan ketegasan dan didukung oleh dalil naqli dari al-Qur'an maupun hadis rasulullah saw.

Secara ekonomis, Islam tidak mengharuskan wanita berpartisipasi dan menanggung beban seperti dalam perdagangan, jabatan fungsional dan sebagainya. Tugas wanita yang adalah mengelola rumah, membentuk dan mendidik anak menjadi pribadi yang benar. Kalimat tidak mengharuskan bukan berarti melarang wanita bekerja. Mereka boleh melakukan aktivitas ekonomi asalkan

27 Abu Rifqi al-Hanif, dan Lubis Salam, Analisa cirri-ciri Wanita Muslimah, (Surabaya: Terbit Terang, t.th.), hlm. 7 
tugas utama tidak terlantar. Istri Rasulullah, Khodijah r.a adalah pengusaha yang berhasil, tetapi beliau wanita yang terhormat, berakhlak tinggi, hijab tetap ditegakkan dalam segala aktivitasnya.

Dengan demikian Islam tidak melarang wanita berkarir, tetapi mengharuskan wanita mengurus rumah dan keluarganya. Sebaliknya Islam mengharuskan pria bekerja dan menganjurkan pria membantu istrinya mengurus rumah tangga sebagaimana dicontohkan Rasulullah. Wanita diperbolehkan bekerja membantu penghasilan suaminya, asalkan tetap menjaga hukum, memelihara diri dan kehormatannya sebagaimana Islam telah menjaganya. Sebenamya wanita muslimah bisa berperan pada aktivitas sosial, seperti mengurus yayasan yatim piatu, syi'ar Islam di kalangan kaum wanita juga bisa bergerak di bidang perluasan ilmu pengetahuan, melalui kelompok pengkajian, pendidikan bagi anak-anak, penelitian tentang gizi, menjadi suster di rumah sakit Islam untuk mengurus pasien putri, menjabat direktur atau sekretaris yang mengelola madrasah-madrasah putri. Dari semula wanita sudah mempunyai lingkup kegiatannya sendiri yang kini dapat dikembangkan dalam skala besar, seperti sektor jasa boga, industri rumah tangga, industri obat-obatan. Bila kaum pria adalah proaktif dari pekerja sektor industri, kaum wanita adalah proaktip dari pekerja dalam bidang jasa informatika dan masih banyak lagi pekerjaan yang sesuai dengan kodrat penciptaannya.

Syari'at Islam tidak melarang wanita bekerja selama adab syar'i tetap dijaga, tidak terjadi ikhtilath antara pria dan wanita sehingga secara minim tidak produktif. ${ }^{28}$ Perlu dikatahui bahwa busana muslimat awal satu langkah untuk membentuk pribadi yang luhur untuk kesempurnaan ibadah dan akblak. ${ }^{29}$ Dalam agama Islam ada beberapa tata krama seorang wanita yang memiliki aktivitas di luar rumah, diantaranya:

${ }^{28}$ Muhammad Amman ibn Ali Al Jami' (1984) "Pelita Rumah Tangga Islam” (Wanita Karir), hlm. 15

${ }_{29}$ Dan bukan berarti bahwa orang yang memakai jilbab itu mesti baik akhlaknya da budi pekertinya, tetapi dengan berbusana musimah (jilbab) adaah satu usaha untuk menuju kesempurnaan akhlak. Lihat Baidowi. Wanita Dan Jilbab... hlm. 183
1. Tidak keluar rumah kecuali seizin suaminya, hendaknya ia keluar dengan tidak bershias mencari jalan yang sepi dan tidak ditempat ramai, menjaga suaranya agar tidak mengundang nafsu laki-laki.

2. Menjaga kehormatan suaminya serta mendukung dan mendorong pekerjaan suaminya, tidak berniat menghianti suami dan hartanya.

3. Senantiasa memperbaiki dirinya dan mengatur rumah tangganya dengan baik, tidak melupakan kewajibannya sebagai hamba Allah dan sebagai seorang istri.

4. Senantiasa merasa cukup dengan pemberian suaminya dari rezki yang diberikan Allah.

5. Hendaknya ia mendahulukan hak suami dibandingkan hak dirinya dan sahabatnya.

6. Tidak mengungkit-ungkit kesalahan suami.

7. Istri tidak membangga-banggakan kecantikannya dan melecehkan keburukan suaminya. ${ }^{30}$

Selanjutnya Islam melihat hukum wanita karir adalah mubah, selama ia masih menjaga kodratnya sebagai wanita, sebagai ibu dan sebagai istri dan apa yang diperolehnya merupakan suatu ibadah sedekah terhadap rumah tangganya. Namun hukum tersebut bisa berubah menjadi haram, bila para wanita melalaikan tugasnya dan bekerja tanpa izin suaminya.

\section{Probelmatika Wanita Karir dan Pemecahannya.}

Masyarakat akan sejahtera apabila warganya berakhlak luhur, di mana terdapat kesadaran umum tentang pentingnya hukum Allah. Dan sebagai standar khususnya bila wanita sudah bisa dikendalikan maka akan terwujud keluhuran insani. Islam berkepentingan membentuk wanita sholihat, qonitat, abidat yang akan melahirkan putraputri beriman. Peranan penting yang dimainkan wanita hari ini besar sekali artinya dalam membentuk generasi mendatang. Tapi sekarang

30 Al-Gazali, Rahasia Dibalik Tirai Pernikahan, (Jakarta: Kalam Mulia, 2001) Cet. Ke 1, hlm. 164 
wanita dihadapkan pada dua kekuatan, satu kekuatan baik yang memberinya gambaran tentang kebaikan, sementara kekuatan lain menariknya untuk bergabung ke dalam pegerakan-pergerakan wanita agar berperan mencapai kemajuan, kejayaan dan cita-cita serta meraih beberapa prestasi dan prestise dan apa saja yang didambakannya.

Memang banyak orang menghendaki agar wanita keluar dari kewanitaannya, yang sebenarnya merupakan modal dan kekayaannya yang utama. Dan jika benar-benar terjadi maka wanita takkan ada lagi nilainya. Sementara mereka tidak mengerti, bahwa pemberian hak wajib disesuaikan dengan kekuatan dan kemampuan yang ada. Sebab bila wanita memikul beban melebihi batas, ia sendirilah yang akan mengeluh meskipun di depan khalayak berpura-pura kuat menanggungnya. Tidak sedikit orang yang berhasil menapak karirnya hingga menuju puncak berkat bimbingan orang lain. Harus kita akui bahwa ilmu yang kita peroleh dari sekolah hanyalah teoritis yang kadang bertentangan dengan fakta di lapangan, dengan sendirinya untuk mendapatkan pekrjaan perlu keahlian khusus. Yakni keahlian membaca keadaan lalu mensiasatinya apalagi bila ingin menjadi seorang yang professional, harus lebih banyak belajar. ${ }^{31}$

Di era modernisasi ini, banyak pilihan yang menjebak wanita, berbagai dalih yang dipoles. Kaum hawa dieksploitir, macam dan ragamnya berwarna-warni. Isu sentral dihembuskan emansipasi. Atas nama itu pula kaum wanita dikubur hidup-hidup. Betapa tidak, atas nama undang-undang prostitusi, bursa seks tumbuh subur, tidak hanya itu. Gadis cantik menjadi sasaran bursa internasional, mereka dijadikan gadis sampul, iklan, ratu kecantikan dan pramugari. Kecantikan parasnya, kesintalan tubuhnya, kelembutan gerak serta tutur katanya telah dieksploitasi habis-habisan. ${ }^{32}$ Mereka telah

31 Syamsul Rijal Hamid, Ridho Allah tergantung Ridho Orang Tua, (Bogor: Cahava Salam, 2008), Cet. Ke 1, hlm. 34

${ }^{32}$ Lihat juga Baidowi Suamsuri, wahai gadis pramugari apakah engkau belum berfikir bahwa engkau kini telah dipasang untuk melayani penumpang kapal terbang lantaran kecantikanmu, dan apakah bisa bertahan dengan lama kalau kulit mulai keriput apakah anda akan dipasang lagi, kalau demikian bukankah anda itu 92 terperangkap dengan komersialisasi sesat. Perbudakan atas nama emansipasi memang perlu dicegah. Kita mesti mengkaji ulang pada tata nilai yang sama-sama kita yakini kebenarannya, Islam bagaimana menjadi muslimah, tata nilai Islam yang bersumber pada al-Qur'an dan hadis, menjawabnya tuntas. Islam datang membawa kedamaian, bendera kecerahan yang akan mengangkat tinggi harkat kemanusiaan umat. Karir meski mengundang gaji cukup, kalau tanpa adanya hijab, hanya akan mendatangkan fitnah dan keretakan rumah tangga. Jelas Islam dengan syariatnya yang paripurna telah membatasi pola kerja yang tidak normatif, Islam penuh waspada akan bahaya yang akan menimpa umatnya.

Dengan bekerja diluar rumah wanita akan banyak bergaul dengan kaum lelaki, apakah semua pihak bisa menegakkan syariat dan hijab sebagaimana di zaman Rasulullah semua kepentingan bersama wanita harus dilakukan di balik tabir agar mereka tidak terganggu. Secara logika, apabila meminta barang kepada Ummul mukminin saja harus di balik tabir, maka lebih-lebih kepada perempuan biasa. Sebab Ummul mukminin, iffah dan kesucian mereka lebih terjaga, sedang perempuan biasa belum terjamin iffah dan kesuciannya.

Karir itu tak selamanya harus di luar rumah, tetapi bagaimanapun dapat mengurangi amanah pokok wanita. Wanita yang punya kelembutan, kesabaran dan kehangatan. Ini adalah modal pokok untuk mendidik anak-anak mereka. Juga kasih sayang sang suami, kalau wanita harus menyita waktu untuk kerja di luar rumah maka tentu nilai-nilai itu tergeser, ia akan berubah menjadi wanita yang tegas, banyak bersifat otoriter dan idealis, serba ingin berkuasa karena memang situasi mendukungnya, hingga lepas kontrol, maka kepada siapa anak-anak bermanja, saat suami pulang kerja penuh lelah siapa yang akan melerainya, apalagi bila keduanya sibuk maka tugas rumah tangga akan terbengkalai.

Wanita yang terkadang lebih maju dalam karir juga akan menimbulkan ego, merasa lebih tinggi dari suami dan seterusnya.

bagaikan barang dagangan kalau masih dibutuhkan ia akan dipuja-puja, kalau sudah bosan akan dibuang ketempat sampah. Ibid. hlm 89 
Tugas utama wanita adalah bergumul dengan makhluk Allah yang paling mulia yaitu manusia. Wanita sebagai istri bergumul dengan suami, menenangkan, menentramkannya agar dia senang dan betah hidup di tengah-tengah keluarga. Wanita sebagai ibu, mengandung janin, melahirkan anak, menimangnya, mengasuh dan menyusuinya, memelihara dan mendidiknya, menyiapkan untuk hari esok yang lebih baik. Menyiapkan untuk menghadapi segala macam perjuangan, mengisi mental dan jiwanya dengan akhlak, budi pekerti dan moral yang tinggi. Usia bayi dan masa anak-anak serta kemampuan untuk mandiri bagi manusia lebih lama dan panjang, waktu yang lama itulah yang menjadi tugas wanita untuk menangani dan mengisi. Jika ayah keluar, anak tinggal bersama ibunya. Sampai usia 6 tahun akalnya belum sempurna. Ibulah yang berhak mengisi dan menyempurnakannya. Apabila ibu sibuk di luar rumah dengan karirnya, kepada siapa anak diserahkan, kepada pengasuh atau pembantu rumah tangga, mungkinkah pengasuh dapat dipercaya penuh kasih sayangnya, sesungguhnya kasih sayang itu tak setara kasih sang ibu kandung, mereka anak-anak tanpa keluarga, lantaran kedua orangtuanya sibuk di luar rumah. Padahal bila kita hayati ternyata generasi semacam ini akan mengalami banyak kemunduran dan keterbelakangan.

Upaya seorang wanita dalam membina putra-putrinya akan menguntungkan pribadinya, sebab siapa yang tak suka terhadap generasi shaleh yang akan mendoakan kita kelak, bukankah salah satu amal yang tak terputus adalah doa anak yang shaleh, mutiara hikmah telah mengubah, "Putra putrid adalah tunas harapan, hasilnya kelak diketam, merekalah cendra mata ayah bunda".

Oleh karena itu jangan sia-siakan waktu, karena memburu karir, binalah anak-anak penuh kasih sayang, keberadaan wanita di luar rumah tentu akan mengurangi kasih cintanya pada anak. Islam adalah dien, pembawa kebaikan bagi Islam adalah benteng yang kokoh, pelindung wanita, menaungi anak-anak penuh setia. Karir yang hanya melacurkan wanita dilarang keras oleh Islam. Islam melarang tegas wanita keluar rumah dengan hiasan menawan, menarik simpati, berparfum, bermode ala jahiliyah yang merangsang dan menimbulkan 94 fitnah bagi pria, wanita semacam ini sama halnya dengan berzina, berdasarkan hadis nabi dari Abu Musa al-Asy'ary:

"Apabila seorang wanita menggunakan wangi-wangian lalu ia berjalan di suatu majelis, sedang ia bergaya ini itu, maka ia telah berzina" (H.R. Tirmidzi)

Wanita semacam ini tak ubahya dengan makanan lezat disuguhkan di tengah jalan, tepian air menggenang dalam keadaan terbuka, lalu dihinggapi serangga datang mencicipi, lalatpun berkeliaran di sekitarnya akhirnya sempat bertelur diatasnya, bahkan anjing jalanan melahapnya penuh lezat. Inilah perumpamaanperumpamaan yang besar kemungkinan akan timbul pada mereka yang banyak keluar rumah dengan menampakkan hiasan, membuka aurat, menebarkan harum-haruman. Oleh karena itu hendaklah wanita menutupi auratnya dengan tertib dan sopan, menjaga diri penuh kesucian sebagaimana Islam telah memeliharanya. Hayatilah betapa besar perhatian Islam terhadap wanita, agar mereka terhormat, luhur mulia yang akan menjernihkan citra rumah tangga muslim. Sebab dialah kelak akan mewarnai wajah zaman. ${ }^{33}$

Demikianlah pentingnya nilai wanita sebagai tiang negara, bangsa dan umat, wanita muslimah ditempatkan sebagai suatu yang teramat mahal harganya, dunia ini mata' (perhiasan atau kenikmatan) dan sebaik-baik perhiasan adalah wanita yang sholihah. Karena itu wanita muslimah harus menyadari posisinya. Tugas pokok adalah menjadi istri dan ibu yang baik, yang kelak akan melahirkan manusiamanusia teladan. Seperti telah diperankan ibu Musa, Maryam, Khadijah r.a. (ibu kaum mukminat) dan lain-lain. Betapa bahagianya seorang ibu yang mempunyai suami dan anak-anak teladan, meski dirinya sendiri tenggelam dalam kesibukan rumah tangga. Sebab Allah akan memberi derajat yang sama dengan suami dan anak-anak yang shaleh, bahkan ia mendapat lebih dari itu, lantaran ketulusan dan pengabdiannya suami dan anak-anak menjadi manusia kekasih Allah. Sungguh tiada arti segala gemerlapan emansipasi di luar rumah, dibandingkan dengan nilai seorang ibu yang mendidik, mendukung

33 Syamsul Rijal, Ridho Allah, hlm.35 
suami dan anak-anaknya untuk menjadi mujabid (pejuang) yang siap membela dienullah. Gaji besar, kedudukan tinggi, rumah mewah, kemasyhuran, sederetan pangkat dan gelar dan sejenisnya yang diraih seorang wanita lantaran berharu biru di luar rumah, sesungguhnya suatu kebahagiaan semu, sebab pada akhirnya ia akan kehilangan harta kekayaannya yang lebih besar yaitu anak dan suaminya. ${ }^{34}$

Apa yang terjadi di barat telah menunjukkan segala kemuraman tersebut. majalah Times melaporkan, kebanyakan wanita, rumah tangga di Amerika dan Eropa berada dalam suasana broken home mereka dilanda kegundahan dan kegelisahan luar biasa dahsyatnya, mereka hidup dikelilingi kemaksiatan, kebejatan akhlak dan moral serta kehancuran fitrah kemanusiaan. ${ }^{35}$

Keadaan sakit parah dan kegelisahan itu sesungguhnya yang ingin mereka tularkan kepada wanita muslimah, keluarga dan masyarakatnya melalui slogan emansipasi, kebebasan, kemajuan, modernisasi dan sebagainya. Ajakan dan slogan emansipasi yang bermakna keluarnya wanita dari rumah untuk berlomba-lomba mengejar kebanggaan duniawi adalah suatu perangkap yang membelenggu. Suatu penjara yang membuat wanita diikat ketat ranta nafsu setan. Sebab begitu ia melangkahkan kakinya keluar untuk maksud tersebut, mulailah memancar aneka ragam dosa dan kemaksiatan. Rangkaian selanjutnya, setelah seorang wanita melangkahkan kakinya adalah terbukanya aurat, mewabahnya pergaulan bebas, runtuhnya sakinah dan kedamaian rumah tangga lantaran istri lebih suka berdandan untuk orang lain daripada untuk suaminya, tumbuhnya generasi muda yang lemah dan rusak gara-gara orang tua pecah dan sibuk melayani masyarakat sembari mengabaikan kebutuhan kasih sayang anak-anaknya. Tidak berarti, wanita dilarang keluar rumah, menikmati udara segar, memberikan sumbangsih dan partisipasi pada aktivitas masyarakat, bahkan Islam memberikan kesempatan untuk semua itu asal sesuai dengan syariat dan kodratnya.

${ }^{34}$ Ibid, hlm. 36

${ }^{35}$ Laila Iksa, Wanita Karir., hlm. 48
Sejarah Islam kaya dengan wanita-wanita perkasa dan teladan yang aktif di tengah-tengah masyarakat.

Ibu kaum mukminat Khodijah, beliau bekerja keras mengelola perdagangannya demi kemajuan dakwah suaminya rasul teladan Muhammad saw. Demikian pula Khaulah binti Dhiyar, saudara sepupu Kholid bin Walid, panglima pasukan khusus wanita mengalahkan panglima Romanus dari Romawi. Ingatlah kisah Ummu Salamah yang menyertai nabi di perjanjian Hudaibiyah. Dialah orang yang berhasil membesarkan jiwa nabi pada saat para sahabat guncang oleh penerimaan perjanjian Hudaibiyah. Ummu Imarah Nusaibah alAnshari wanita yang berjuang di garis depan bersama-sama nabi. ${ }^{36}$ Bahkan ia menjadi tameng bagi Nabi ketika beliau diserang tombak dan anak panah. Nusaibah yang juga menangis ketika anak bungsunya syahid di medan jihad, tapi ia menangis bukan lantaran kematian anaknya itu, tapi karena tak ada lagi yang bisa disumbangkan untuk dakwah di jalan Allah.

Semua fenomena di atas menjelaskan terang, betapa wanita Muslimah dapat bergerak dan melangkah memfungsikan potensi dan keterampilannya tanpa harus mengorbankan kehormatan dan kesucian dirinya, sebab akhlak adalah kunci diutusnya nabi, "Aku diutus ke dunia unluk menyempurnakun akhlak al-karimah". Akhlak itulah kunci keberhasilan eksistensi suatu masyarakat, bangsa dan amal. Tanpa akhlak, bangsa dan masyarakat tak lebih dari hewan-hewan yang gentayangan tiada kebaikan yang dapat diharapkan darinya, hampa tak bermakna.

Masyarakat (ummat) adalah yang memiliki moralitas tinggi, jika tiada akhlak maka tiada arti masyrakat tersebut. Malu kepada Allah SWT., dengan sebenar perasaan malu adalah menjaga kepala dengan segala apa yang bisa ia lakukan, mendengar, melihat dan berbicara dan beserta apa yang ia kandung dan mengingat kematian serta segala bencanananya. Lebih mengutamakan kepentingan akhirat dari kepentingan dunia, maka barang siapa yang melakukan itu semua ia

36 Abdul Qodir Ahmad Atha, Adabun Nabi, (Beirut: Pustaka Azzam, 2000) Cet. Ke 2, hlm.186 
telah malu kepada Allah dengan sebenarnya.Yang akhirnya semua aktivitas oleh seorang muslimah baik di rumah maupun bagi wanita yang memiliki karir di luar rumah hendaknya selalu memilki rasa malu agar semua tindakan yang dilakukan benar-benar menjaga kehormatan dan tidak mamancing lawan jenisnya untuk lebih bersimpati padanya. ${ }^{37}$

\section{Kesimpulan}

Islam sebagai dien integral, syamil mutakamil, paripurna memberikan hak penuh kepada wanita, sebagai penghormatan sesungguhnya. Islam tidak melarang wanita keluar rumah, menikmat udara segar, memberikan sumbangsihnya untuk masyarakat dan Islam. Islam memberikan kesempatan untuk semua itu. Wanita muslimah dipersilahkan mengekspresikan potensi dan keterampilan dirinya untuk kemaslahatan bersama. Ia diperkenankan berbuat, bergerak, namun harus sesuai dengan tuntutan Islam. Wanita muslimah boleh bekerja membantu suaminya, asal tidak memamerkan aurat atau menimbulkan kesombongan. Ia boleh keluar rumah untuk suatu urusan yang dibenarkan syariat, tidak mengorbankan kehormatan dan kesucian dirinya. Wanita muslimah boleh menghayati hakekat suatu pekerjaan dan peran utamanya adalah ratu keluarga, petaka rumah tangga yang akan melahirkan manusia-manusia teladan, sebab dialah tiang negara, maju mundurnya negara tergantung pada wanitanya. Emansipasi, serangan gencar yang demikian menyerbu rumah tangga muslim adalah tantangan ulama yang harus dijawab dengan kejernihan pandangan, arif dan dewasa, sebab ketidakberdayaan menghadapi dan menjawab tantangan ini berarti hancurnya basis pertahahan dan kesucian masyarakat Islam. Karir yang menelantarkan amanah Allah hanya akan mengundang banyak problem, kesulitan, rumit dan komplek dan cendenmg lalai pada fitrah, sementara letak dasar wanita paripurna harus tetap di rumah.

\section{Bibliografi}

${ }^{37}$ Ibid, hlm. 187
Abdul Aziz bin Abdullah, 50 Nasehat untuk Wanita Muslimah, (Jakarta: Gema Insani, 1994).

Amman ibn Ali al-Jami', Muhammad, Pelita Rumah Tangga Islam (Wanita Karir), (Bandung: Pustaka Setia, 1984)

Asyaukani, Luthfi, Politike Ham Dan Isu-isu Teknologi Dalam Fikih Kontemporer, (Bandung : Pustaka Setia, 1998).

Atha, Abdul Qodir Ahmad, Adabun Nabi, (Beirut: Pustaka Azzam, 2000).

Farjy, Najwan, Pedoman Pembinaan Anak Dalam Islam, (Jakarta: Unisef, 1986).

Gazali, Rahasia Dibalik Tirai Pernikahan, (Jakarta: Kalam Mulia, 2001).

Hanif, Abu Rifqi, dan Lubis Salam, Analisa ciri-ciri Wanita Muslimah, (Surabaya: Terbit Terang, t.th.).

Hasymi, Muhammad Ali, Jati Diri Wanita Muslimah, (Jakarta: Gema Insani, 2004).

Iksa, Nurlaila, Karir Wanita Di Mata Islam, Jakarta : Pustaka Amanah, 1998).

Lubis, Nur Ahmad Fadhil, Yurisprudensi Emansifatif, (Bandung: Cita Pustaka Media, 2003).

Mahmud, Ali Abdul Halim, Akblak Mulia, (Jakarta: Gema Insani, 2004).

Muhammad bin Ibrahim dkk, Panduan Ibadah Wanita Muslimah, (Yogyakarta: Darussalam Offset: 2004).

Muqbil, Abdul Aziz Bin Abdullah, 50 nasehat Untuk Wanita Muslimah, (Jakarta: Gema Insani, 2004)

Nasution, Harun, Islam Ditinjau Dari Berbagi Aspeknya, (Jakarta: UII Press, 1985).

Nata, Atang Abddudin dan Jaih Mubarok, Metodologi Studi Islam, (Bandung: Remaja Rosda Karya: 2003). 
Rijal Hamid, Syamsul, Ridho Allah tergantung Ridho Orang Tua,( Bogor: Cahaya Salam, 2008).

Rose, La, Dunia Wanita Rumah Tangga, Memiliki Seribu Tangan. (Jakarta: Pustaka Kartini, 1989).

Syamsuri, Baidowi, Wanita Dan Jilbab, (Surabaya: Anugrah, 1993).

Syuqqah, Abdul Halim Abu, Kitab Tahrirul Mar'ah Fii Ashrir Risalah,

Zainuddin dan Muhammad Jamhari, Al-Islam 2 Muamlab dan Akblak, (Jakarta: Pustaka Setia, 1990) 